\title{
Erratum to: From the Journal archives: Cyclopropane: induction and recovery with a bang!
}

\author{
Michael P. Bokoch, MD, PhD • Adrian W. Gelb, MBChB
}

Published online: 4 July 2014

(C) Canadian Anesthesiologists' Society 2014

\section{Erratum to: Can J Anesth/J Can Anesth DOI 10.1007/s12630-014-0109-x}

In the article entitled: "From the Journal archives: Cyclopropane: induction and recovery with a bang!" published Online First and in the print version of the August 2014 issue of the Journal, Can J Anesth 2014; DOI 10.1007/s12630-014-0109-x, the following Editors' Note should have been included. The publisher apologizes most sincerely for this error.
The online version of the original article can be found under doi:10.1007/s12630-014-0109-x.

M. P. Bokoch, MD, PhD · A. W. Gelb, MBChB ( $\square)$

Department of Anesthesia \& Perioperative Care,

University of California, San Francisco, 521 Parnassus Ave,

C450, San Francisco, CA 94143-0648, USA

e-mail: gelba1@anesthesia.ucsf.edu

\section{Editors' Note: Classics Revisited}

Key Articles from the Canadian Journal

of Anesthesia Archives: 1954-2013

As part of the Journal's $60^{\text {th }}$ anniversary Diamond Jubilee Celebration, a number of seminal articles from the Journal archives are highlighted in the Journal's $61^{\text {st }}$ printed volume and online at: www.springer.com/12630. The following article was selected on the basis of its novelty at the time of publication, its scientific merit, and its overall importance to clinical practice: Lucas $G H W$. The discovery and pharmacology of cyclopropane. Can Anaesth Soc J 1960; 7: 237-56. Drs. Michael P. Bokoch and Adrian W. Gelb provide expert commentary on the discovery and use of a remarkable hemodynamically stable, rapid onset of action, anesthetic gas, the widespread use of which ultimately ended due to its proclivity for explosion.

Hilary P. Grocott MD, Editor-in-Chief

Donald R. Miller MD, Former Editor-in-Chief 